\title{
UDC 621.9.15
}

\section{HEAVY VERTICAL LATHE EQUIVALENT ELASTIC SYSTEM MODELING}

\section{Yevheni Myronenko; Serhii Mirantsov; Denys Huzenko}

\author{
Donbass State Engineering Academy, Kramatorsk, Ukraine
}

\begin{abstract}
Summary. A technological system model of a heavy duty vertical turning and boring mill is proposed in the article. Structural model of technological system and its components including an assembly tool for heavy duty machinery is examined. A design scheme of the ,slide - tool" system is suggested. A simulation model of the technical system behavior is presented, implemented in Simulink MatLab software environment.

Key words: heavy duty vertical turning and boring mill, technological system, cutting process, assembly tool, simulation model.
\end{abstract}

Received 02.06.2016

Formulation of the problem. Current economic conditions under which machinebuilding and machine-tool enterprises operate presently require continuous growth of productivity in machining and reducing consumption of energy resources. In this regard the task of increasing productivity and efficiency of machining of heavy and unique machines is currently relevant [1].

Characteristic feature of running a cutting tool and the purpose of cutting mode elements of a heavy duty vertical turning and boring mill is the fact that in various operations there are large differences in rigidity and, especially, in technological system vibration resistance.

Machining performance of heavy lathes, particularly those of vertical type, is determined by many factors. One of the factors, limiting the performance, is the process occuring in the technological system during processing. It includes random errors and fluctuations arising during operations of rough and final turning and boring.

One of a number of reasons causing vibrations of a vertical lathe technological system during turning and boring is a long slider overhang and insufficient modular tool rigidity, which leads to technological system rigidity decrease.

Analysis of previous research results. Many authors [2, 3, 4] when constructing models of technological systems and researching dynamic phenomena occurring during cutting process (change of cutting forces, vibrations of the elements of equivalent elastic system of machine tool, part, analysis of accuracy of the system and its stability), follow different approaches. The most widely used for research is the closed dynamic system, the elements of which are: the cutting process, the equivalent elastic system (EES) of the machine tool, external excitation, random and systematic errors and also phase characteristic changes of the cutting force, which are taken into account.

In relation to technological systems of heavy and unique machines a number of authors $[5,6,7]$ shows the necessity of taking into account a modular tool as a separate subsystem in the model of technological system that provides the ability to simulate and optimize not only the parameters of the system, but constructive and geometrical parameters of the cutting tool as well.

The objective. Development of a technological system model of heavy machine tools of turning and boring group for determination and optimization of the parameters of technological system with the aim of improvement of the performance and efficiency of processing, taking into account assembly tool as a separate subsystem. 
Problem and methods of experimental research. For the analytical study of dynamic phenomena occurring during the cutting process by heavy duty vertical turning and boring mills a structural and mathematical model of the technological system is proposed.

This model is based on the analysis of structures and design features of a number of heavy vertical lathes with faceplate diameter $\mathrm{D}=(6,300 \ldots 12,000) \mathrm{mm}$. For modeling such heavy machines as 1532, 1565, 1570,1580L were considered, exploited by the „EMSS“ Public Company and the „NKMZ“ Public Company for heavy duty housing workpiece processing with the mass $\mathrm{m}=20,000 \mathrm{~kg}$ (Fig. 1).

For the dynamic phenomena study a closed dynamic system is used most often, which includes cutting process, equivalent elastic system (EES) of the lathe, as well as cutting force phase performance, which are all taken into account.

In this article, for technological system modeling of heavy vertical lathes, as well as for dynamic phenomena calculation and analysis, a structural model is proposed, which includes modular tool as a separate elastic tool subsystem linked up in-parallel with the lathe EES. Structural model of dynamic system with modular tool for heavy duty vertical turning and boring mills is shown in Fig. 2.

Workpieces machined by heavy vertical lathes are generally rigid. Workpiece and tool dimensions are determined by lathe frame size, which can be taken as an indirect indicator of medium hardness and vibration resistance of technological system.
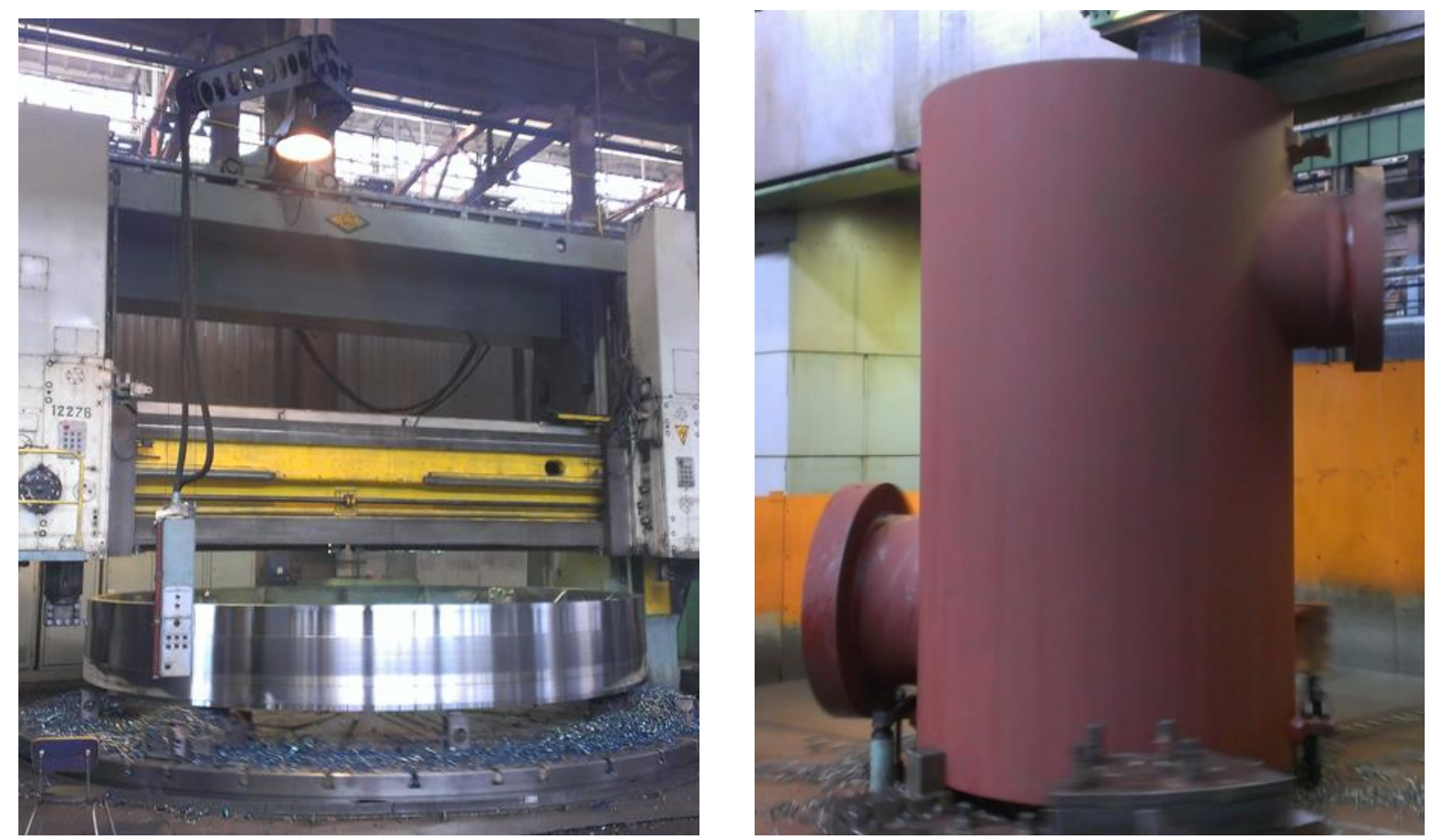

Figure 1. Heavy duty housing workpieces processed by heavy duty vertical turning and boring mills on the sites of the „EMSS“ and the „NKMZ“ Public Companies 


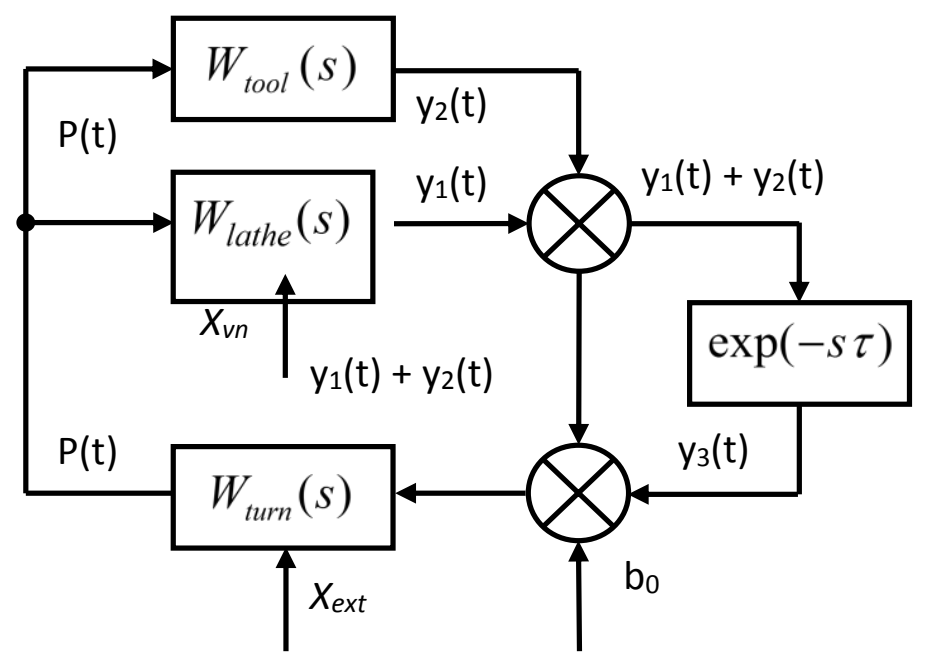

Figure 2. Structural model of dynamic system with modular tool for heavy lathes

The following assumptions are taken to construct the design diagram and the model:

- technological system is seen as a closed by the cutting process set of elements with lumped masses interconnected by linear dissipative and spring linkages;

- all elastic deformation and movement of technological system elements arising from the action of the cutting force components $P x, P y, P z$ occur in elastic members of the system;

- taking into account the workpiece mass and dimensions, the latter is regarded as an absolutely rigid element of the technological system;

- cutting tool is viewed as a subsystem consisting of a housing, subassembly, cutting element (cutting insert) and mechanical fastening elements interconnected by linear dissipative and spring linkages.

In view of the taken assumptions the „portal-slider-tool-workpiece“ technological system of a heavy vertical lathe can be represented by a design diagram, shown in Fig. 3.

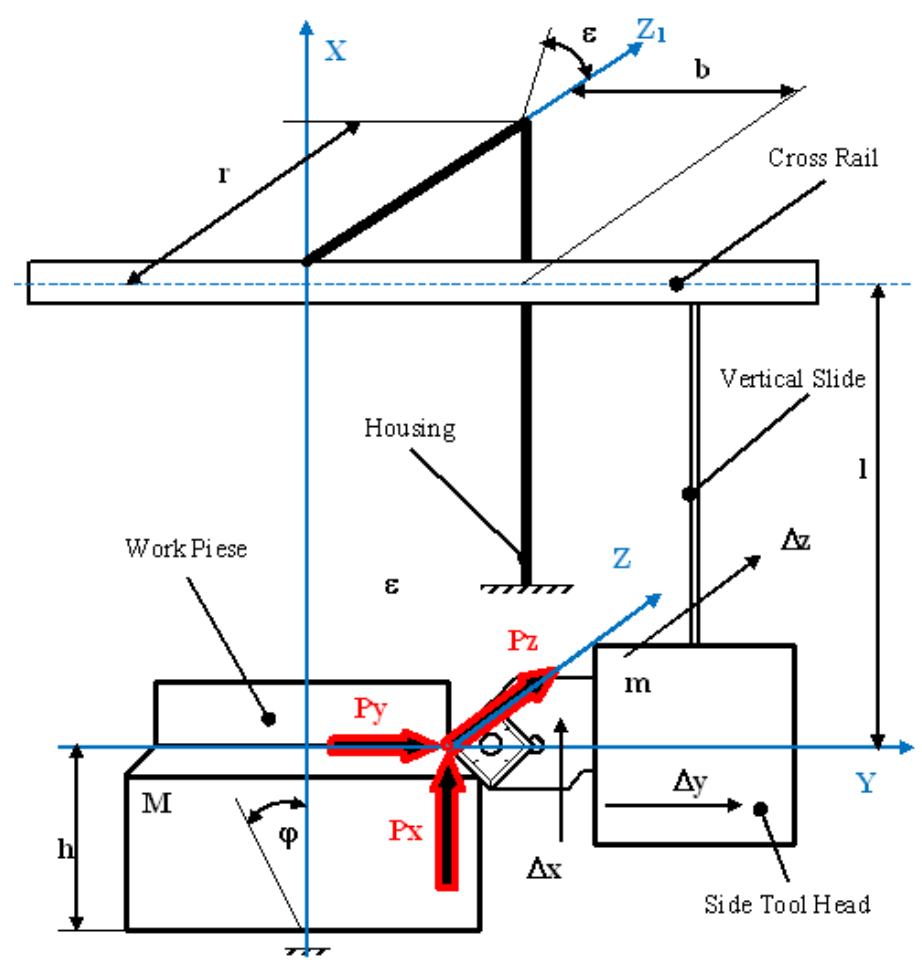

Figure 3. Design diagram of the ,portal-slider-tool-workpiece“ technological system 
Amplitude of vibrations of the ,slide-tool“ system is larger than amplitude of vibrations of lathe support system elements. In this regard the design diagram of the process can be seen in a simpler form, namely as a ,slider-tool“" subsystem as shown in Fig. 4.

In the „slider-tool“ design diagram shown in Fig. 4 the slider is represented in a simplified shape by vertical weightless clamped beam with mass $m$ localized on its end. Under the influence of periodically varying cutting force components, the beam mass $m$, localized on its end, performs longitudinal and transverse oscillations relative to equilibrium position $\mathrm{O}_{1}$. Elastic vibrations are determined by values $\Delta \mathrm{x}$ and $\Delta \mathrm{y}$.

Damping coefficients $C_{x}$ and $C_{y}$ are stipulated by the presence of friction forces in movable joints of the slider system and the presence of ductile friction of the material which the slider is made of. Subject to the presence of modular construction of the tool as well as of the machined workpiece in the system under study, the design diagram of the technological system can be skeletoned as shown in Fig. 5 .
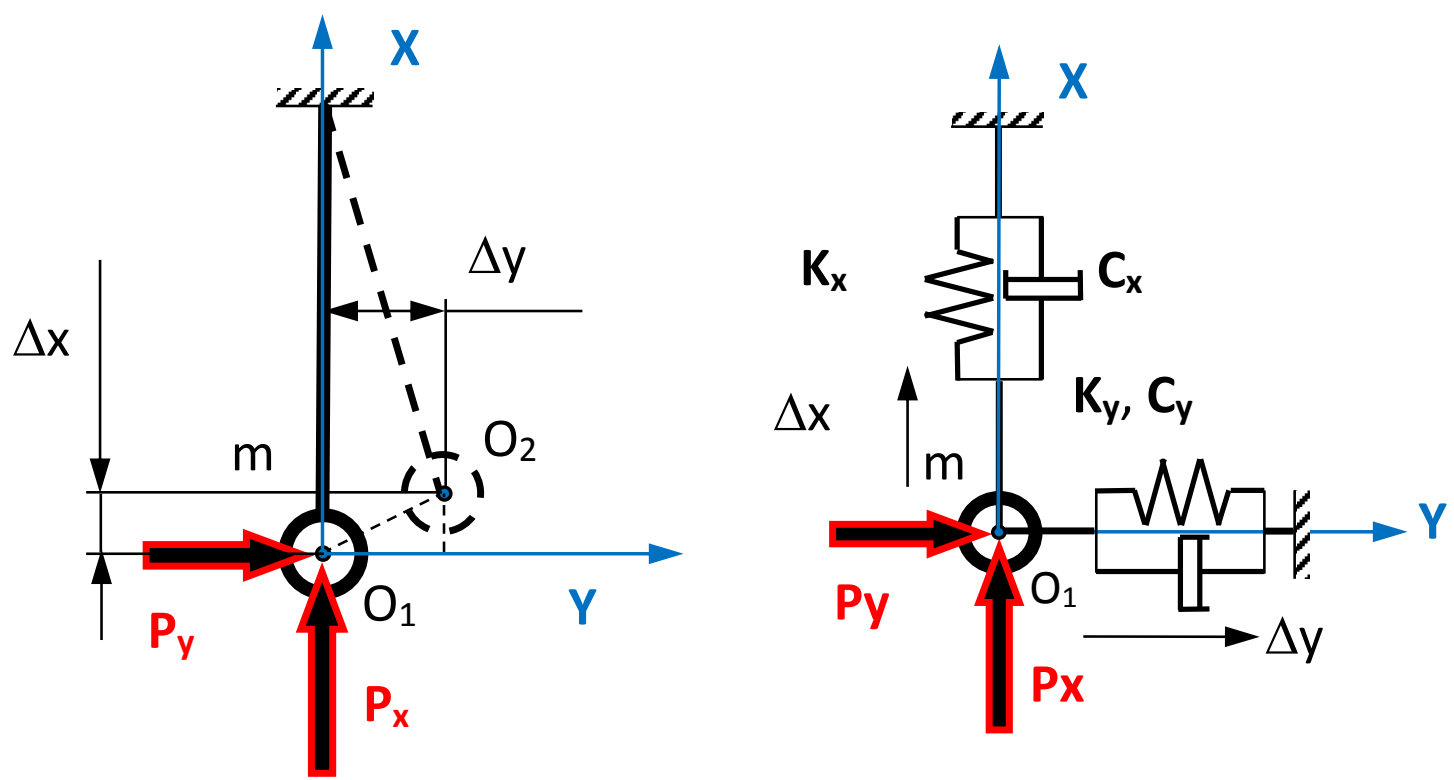

Figure 4. Design diagram of vertical lathe technological system

For generation of equations of motion of elements of the considered technological system Lagrange equation of the second kind is used:

$$
\frac{d}{d t}\left(\frac{\partial T}{\partial \dot{q}_{k}}\right)-\frac{\partial T}{\partial q_{k}}=\sum Q_{k}
$$

where $T$ is kinetic energy of the system, being the function of generalized coordinates $q_{k}$;

$\Sigma Q_{k}$ is the sum of generalized forces acting on the elements of the system;

$q_{k}$ are generalized coordinates. 


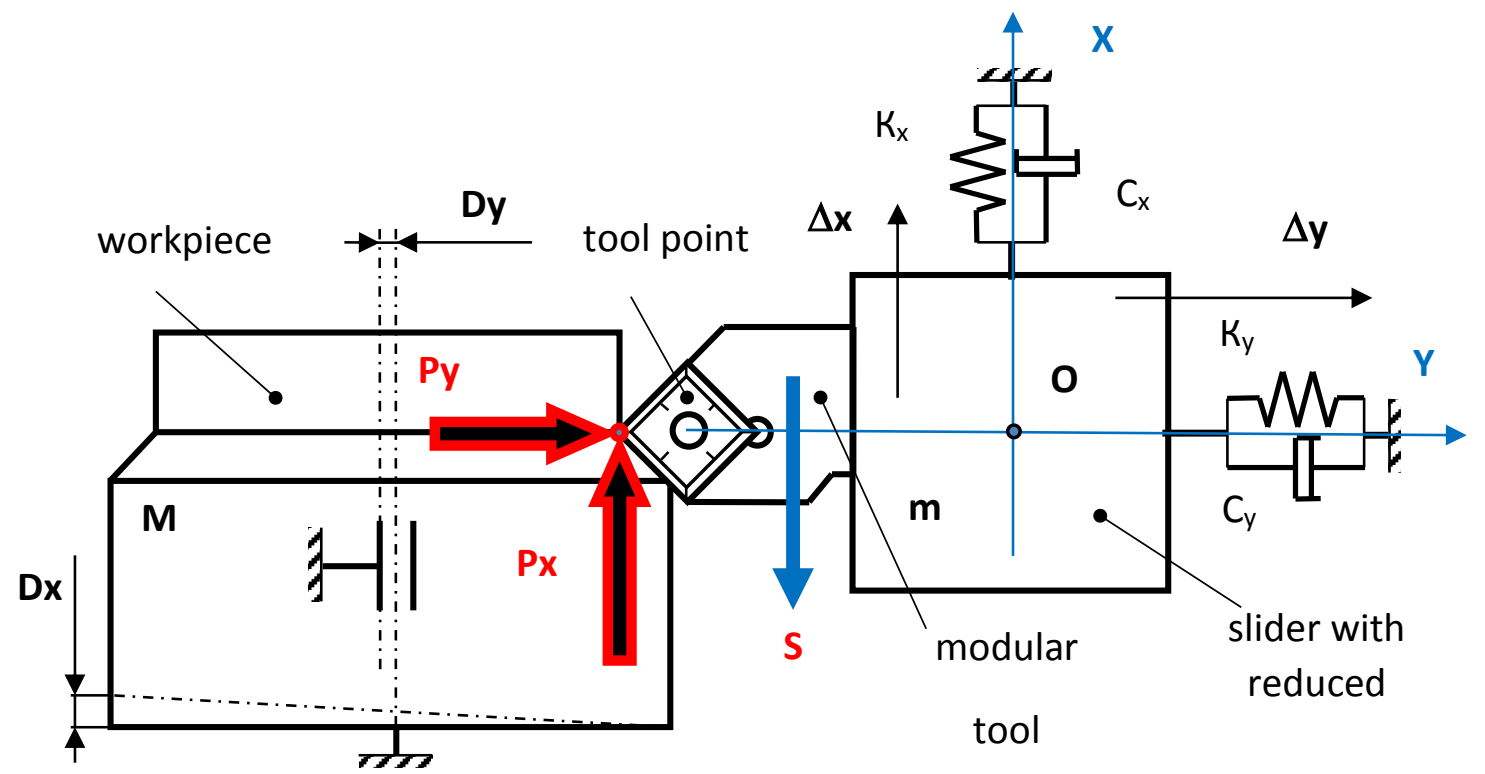

Figure 5. Structural design diagram of heavy duty vertical turning and boring mill technological system

Three types of generalized forces are distinguished in an oscillating system: potential ones $-Q_{U}=-\partial U / \partial q$, being the function of potential energy and generalized coordinates of the system, dissipative ones $-Q_{R}=-\partial R / \partial \dot{q}_{k}$, being the function of friction forces and external forces, for which notation $\Sigma Q_{k}$ is retained. Taking into account the assumed notations Lagrange equation is written as follows [2]:

$$
\frac{d}{d t}\left(\frac{\partial T}{\partial \dot{q}_{k}}\right)-\frac{\partial T}{\partial q_{k}}=-\frac{\partial U}{\partial q_{k}}-\frac{\partial R}{\partial \dot{q}_{k}}+\sum Q_{k}
$$

With a regard to the design diagram shown in Fig. 5, expression for partial kinetic and potential energy of the system in local generalized coordinates is as follows:

$$
\begin{gathered}
\frac{d}{d t}\left(\frac{\partial T_{x}}{\partial \dot{x}}\right)=\frac{d}{d t}\left(\frac{1}{2} \frac{\partial\left(m \dot{x}^{2}+m \dot{y}^{2}\right)}{\partial \dot{x}}\right)=\frac{d}{d t}\left(\frac{1}{2} 2 m \dot{x}+0\right)=\frac{d}{d t}(m \dot{x})=m \frac{d^{2} x}{d t^{2}}=m \ddot{x} \\
\frac{d}{d t}\left(\frac{\partial T_{y}}{\partial \dot{y}}\right)=\frac{d}{d t}\left(\frac{1}{2} \frac{\partial\left(m \dot{x}^{2}+m \dot{y}^{2}\right)}{\partial \dot{y}}\right)=\frac{d}{d t}\left(0+\frac{1}{2} 2 m \dot{y}\right)=\frac{d}{d t}(m \dot{y})=m \frac{d^{2} y}{d t^{2}}=m \ddot{y} \\
Q_{U x}=\frac{\partial U}{\partial x}=\frac{1}{2} \frac{\left(K_{x} x^{2}+K_{y} y^{2}\right)}{\partial x}=\frac{1}{2} 2 K_{x} x+0=K_{x} x \\
Q_{U y}=\frac{\partial U}{\partial y}=\frac{1}{2} \frac{\left(K_{x} x^{2}+K_{y} y^{2}\right)}{\partial y}=0+\frac{1}{2} 2 K_{y} y=K_{y} y \\
Q_{R x}=\frac{\partial R}{\partial \dot{x}}=\frac{1}{2} \frac{\left(C_{x} \dot{x}^{2}+K_{y} \dot{y}^{2}\right)}{\partial \dot{x}}=\frac{1}{2} 2 C_{x} \dot{x}+0=C_{x} \dot{x}
\end{gathered}
$$




$$
\begin{gathered}
Q_{R \psi}=\frac{\partial R}{\partial \dot{y}}=\frac{1}{2} \frac{\left(C_{x} \dot{x}^{2}+C_{y} \dot{y}^{2}\right)}{\partial \dot{y}}=0+\frac{1}{2} 2 C_{y} \dot{y}=C_{y} \dot{y} \\
Q_{x}=P_{x}(\tau), Q_{y}=P_{y}(\tau),
\end{gathered}
$$

where $m$ is the reduced mass of the technological system, $\mathrm{kg}$;

$C_{x}, C_{y}$ are reduced coefficients shown respectively along $\mathrm{X}$ and $\mathrm{Y}$ axes, $\mathrm{N} \cdot \mathrm{sec} / \mathrm{m}$;

$K_{x}, K_{y}$ are reduced stiffness coefficients along $\mathrm{X}$ and $\mathrm{Y}$ axes respectively, N/m;

$P x(\tau), P y(\tau)$ are the cutting force components, $\mathrm{N}$.

Substituting expressions defining kinetic energy of the system and expressions for generalized forces in equation (2), equations of motion of the considered dynamic system elements in $X-Y$ coordinates are obtained.

For model construction the cutting force and its components are considered as a value depending on physical and mechanical properties of the processed material, on tool geometric parameters, as well as on thickness $a(\tau)$ and width $b(\tau)$ of the cut layer [2].

$$
P(\tau)=K \cdot a(\tau) \cdot b(\tau)
$$

where $K$ is the factor depending on physical and mechanical properties of the processed material and tool geometric parameters $\mathrm{N} / \mathrm{m}^{2}$;

$a(\tau), b(\tau)$ are respectively the cut layer thickness and width, defined by specified cut depth and tool feed, mm.

During oscillations in the technological system, caused by turning operations, there appears elastic travel of the tool and technological system elements relative to the workpiece, which leads to the cut modification in thickness $a(\tau)$ and width $b(\tau)$.

Let us consider area modification taking place in the cut layer during turning and boring by vertical lathe, caused by elastic motion of technological system elements relative to the workpiece (Fig. 6).

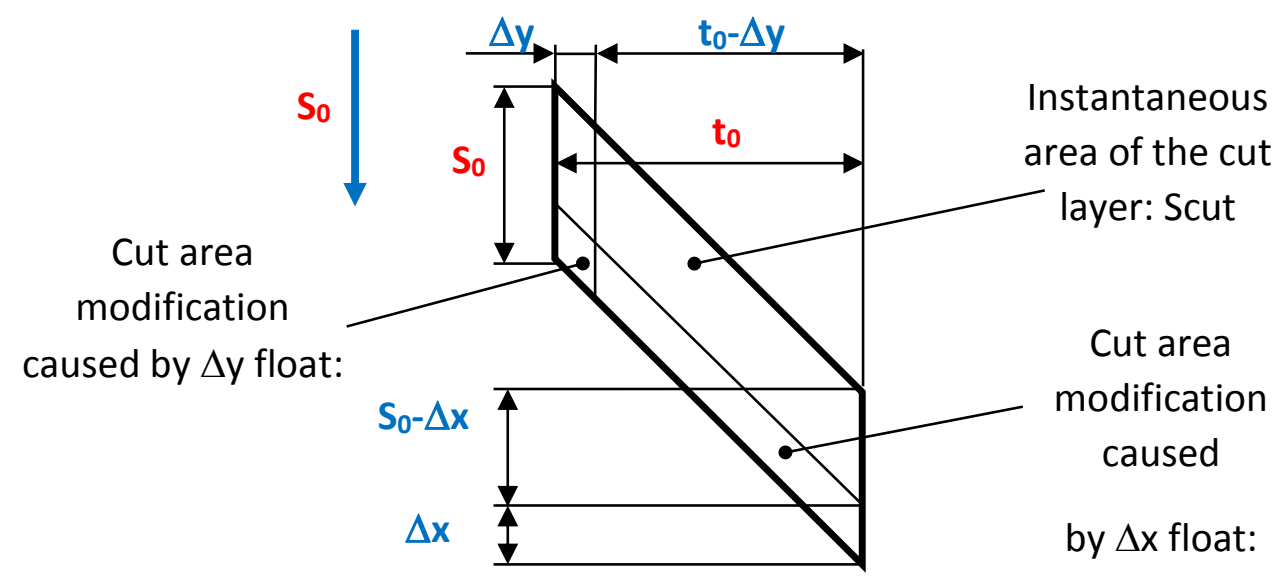

$\Delta S \mathrm{x}$

Figure 6. Diagram of cut area modification during turning and boring by vertical lathe caused by tool vibrations along $\mathrm{X}$ and $\mathrm{Y}$ axes

Taking into consideration expressions (3) equations are obtained determining modifications in cutting force components $P x(\tau)$ and $P y(\tau)$ during tool vibration: 


$$
\begin{aligned}
& P x(t)=\frac{K_{p x}}{\sin \varphi}\left(S_{0}-\Delta x\right)\left(t_{0}-\Delta y\right) ; \\
& P y(t)=\frac{K_{p y}}{\sin \varphi}\left(S_{0}-\Delta x\right)\left(t_{0}-\Delta y\right),
\end{aligned}
$$

where $K_{p x}, K_{p y}$ - are respectively specific values of cutting force components $P x(\tau)$ and $P y(\tau), \mathrm{N} / \mathrm{mm}^{2}$.

In view of the indicated factors, expressions for cutting force components, applied to the case under consideration, take on form:

$$
\begin{aligned}
& P x(\tau)=\frac{K_{p x}}{\sin \varphi} K_{p}(\tau)\left[S_{0}+\Delta D_{x} \cdot \sin \left(\omega \tau+q_{0}\right)-x(\tau)-x(\tau-T)\right]\left[t_{0}-y(\tau)-y(\tau-T)\right] ; \\
& P y(\tau)=\frac{K_{p y}}{\sin \varphi} K_{p}(\tau)\left[t_{0}+\Delta D_{y} \cdot \sin \left(\omega \tau+q_{0}\right)-y(\tau)-y(\tau-T)\right]\left[S_{0}-x(\tau)-x(\tau-T)\right],
\end{aligned}
$$

where $\Delta D_{x}, \Delta D_{y}$ are respectively the inaccuracy of workpiece axes positioning, $\mathrm{mm}$;

$K_{p}(\tau)$ is the coefficient determining modification in cutting force due to random errors occuring during processing;

$\omega$ is the workpiece rotation speed, $\mathrm{rad} / \mathrm{sec}$;

$q_{0}$ is the initial phase of workpiece rotation, rad;

$T$ is the duration of one revolution of the workpiece, sec.

For obtaining of equations describing the motion of modular tool elements, it is assumed that the cutting force components are applied to the mass center of the plate, and the torque resulting from transfer of the point of application is neglected. Frictional forces between mechanical fastening elements influencing the cutting element are proportional to the rate of displacement, and elastic force is proportional to displacement itself [5].

By virtue of the design features of the cutting part of modular cutters, the plate mass center displacement is made up of two movements $\xi$ and $\psi$, the vectors of which do not coincide with the $X$ and $Y$ axes of the global coordinate system. To eliminate this inconvenience and to facilitate obtaining the equations describing vibrations of the tool insert we introduce additional local coordinate system $\Xi-\Psi$, which is rotated relative to the global coordinate system through the $\varphi$ angle so that the $\Xi$ axis is parallel to the main cutting edge of the plate and the $\Psi$ axis is perpendicular to the main cutting edge.

In respect to the design diagram of the modular tool shown in Fig. 7, the following notation is set: $P x, P y$ are axial and radial cutting force components; $P x_{\xi}, P x_{\psi}, P y_{\xi}, P y_{\psi}$ are projections of axial and radial cutting force components, defined in the local coordinate system $\Xi-\Psi ; k \xi, k_{\psi}$ are rigidity coefficients of the insert mounting along the lines of the local axes $\Xi$ and $\Psi ; T \xi, T_{\psi}$ are frictional forces effecting the cutting insert considered local coordinate system.

The proposed design diagram of modular tool is shown in Fig. 7. 


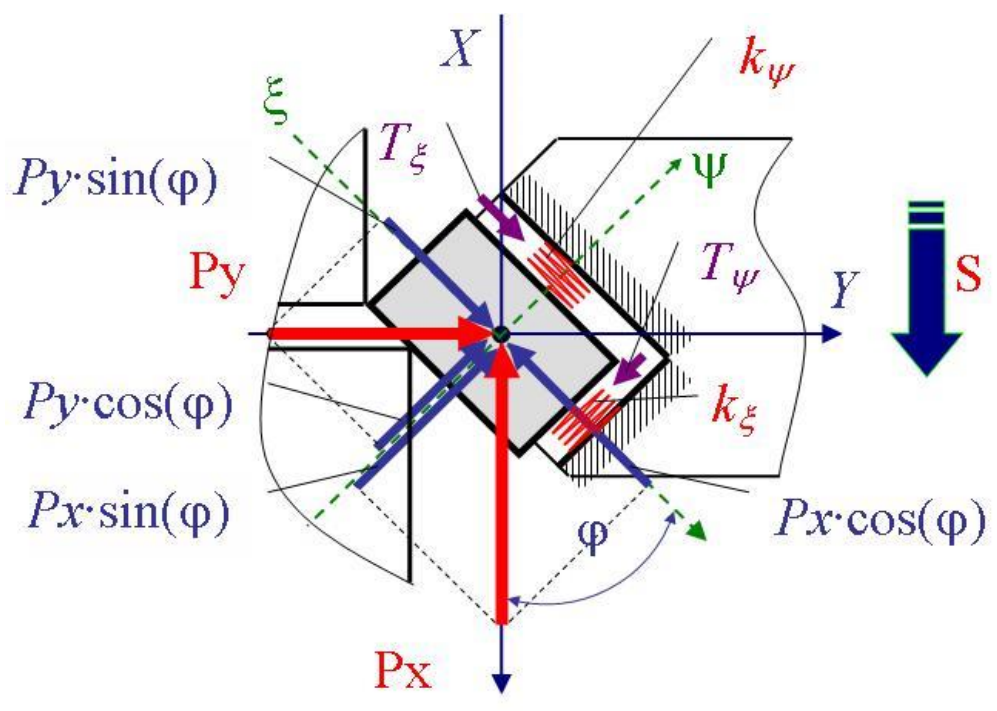

Figure 7. Design diagram of modular cutter

Considering the movement of the cutter elements, it is necessary to define the relationship between movement and projections of actors in global and local coordinate systems.

Dependency between movements in these coordinate systems takes the form:

$$
\begin{aligned}
& y=\psi \cos (\varphi)-\xi \sin (\varphi)=-\xi \sin (\varphi)+\psi \cos (\varphi), \\
& x=-\psi \sin (\varphi)-\xi \cos (\varphi)=-\xi \cos (\varphi)-\psi \sin (\varphi) .
\end{aligned}
$$

Relationship between the projections of the forces is the following:

$$
\begin{array}{ll}
P_{x \xi}=P_{x} \cos (\varphi), & P_{y \xi}=P_{y} \sin (\varphi), \\
P_{x \psi}=P_{x} \sin (\varphi), & P_{y \psi}=P_{y} \cos (\varphi) .
\end{array}
$$

A new notation is introduced: $F_{\xi}, F_{\psi}$ are sum force vectors effecting cutting insert along local axes. The relationship between $F \xi, F_{\psi}$ and $P x$, $P y$ components is:

$$
\begin{gathered}
F_{\xi}=P_{x \xi}+P_{y \xi}=P_{x} \cos (\varphi)+P_{y} \sin (\varphi) \\
F_{\psi}=P_{x \psi}+P_{y \psi}=-P_{x} \sin (\varphi)+P_{y} \cos (\varphi) .
\end{gathered}
$$

The system of differential equations describing the motion of the elements of the system under consideration in local coordinates $\xi-\psi$ is:

$$
\left\{\begin{array}{l}
m \ddot{\xi}+c_{\xi} \dot{\xi}+k_{\xi} \xi=F_{\xi} \\
m \ddot{\psi}+c_{\psi} \dot{\psi}+k_{\psi} \psi=F_{\psi} .
\end{array}\right.
$$

If quantities $F_{\xi}$ and $F_{\psi}$ are expressed through the values of axial and radial components of $P x$ and $P y$ cutting forces, as a result we obtain original system of differential equations in the form:

$$
\left\{\begin{array}{l}
m \ddot{\xi}+c_{\xi} \dot{\xi}+k_{\xi} \xi=P_{x} \cos (\varphi)+P_{y} \sin (\varphi) \\
m \ddot{\psi}+c_{\psi} \dot{\psi}+k_{\psi} \psi=-P_{x} \sin (\varphi)+P_{y} \cos (\varphi) .
\end{array}\right.
$$


To simplify further examination and analysis of the obtained expressions, both parts of differential equations (7) and (8) are divided by the values of $k_{\xi}$ and $k_{\psi}$ respectively, taking the following notation:

$$
m / k_{\xi}=T_{11}^{2}, c_{\xi} / k_{\xi}=T_{12}, m / k_{\psi}=T_{21}^{2}, c_{\psi} / k_{\psi}=T_{22}
$$

The result is a new system of differential equations in the form:

$$
\left\{\begin{array}{l}
\left(T_{11}^{2} s^{2}+T_{12} s+1\right) \xi(s)=\frac{1}{k_{\xi}} P_{x}(s) \cos (\varphi)+\frac{1}{k_{\xi}} P_{y}(s) \sin (\varphi) \\
\left(T_{21}^{2} s^{2}+T_{22} s+1\right) \psi(s)=-\frac{1}{k_{\psi}} P_{x}(s) \sin (\varphi)+\frac{1}{k_{\psi}} P_{y}(s) \cos (\varphi)
\end{array}\right.
$$

The system of algebraic equations (9) allows to directly determine the desired movement of the cutting element in local coordinate system. From the first and the second equations the values of elastic movement $\xi(s)$ and $\psi(s)$ of the insert in local coordinate system are derived.

With the use of the obtained expressions, describing cutting process, movement of EES elements as well as of modular tool subsystem during oscillation, the system of differential equations describing the motion of technological system elements of a heavy vertical lathe takes the form:

$$
\left\{\begin{array}{l}
m \ddot{x}_{\text {mill }}(\tau)+C_{x} \dot{x}_{\text {mill }}(\tau)+K_{x} x_{\text {mill }}(\tau)=P_{x}(\tau) \\
\ddot{y}_{\text {mill }}(\tau)+C_{y} \dot{y}_{\text {mill }}(\tau)+K_{y} y_{\text {mill }}(\tau)=P_{y}(\tau) \\
T_{11}^{2} \ddot{\xi}(\tau)+T_{12} \dot{\xi}(\tau)+\xi(\tau)=\left(P_{x}(\tau) \cos (\varphi)+P_{y}(\tau) \sin (\varphi)\right) / k_{\xi} \\
T_{21}^{2} \ddot{\psi}(\tau)+T_{22} \dot{\psi}(\tau)+\psi(\tau)=-\left(P_{x}(\tau) \sin (\varphi)+P_{y}(\tau) \cos (\varphi)\right) / k_{\psi} \\
P_{x}(\tau)=\frac{K_{p x}}{\sin \varphi} K_{p}(\tau)\left[S_{0}+\Delta D_{x} \cdot \sin \left(\omega \tau+q_{0}\right)-x(\tau)-x(\tau-T)\right]\left[t_{0}-y(\tau)-y(\tau-T)\right] \\
P_{y}(\tau)=\frac{K_{p y}}{\sin \varphi} K_{p}(\tau)\left[t_{0}+\Delta D_{y} \cdot \sin \left(\omega \tau+q_{0}\right)-y(\tau)-y(\tau-T)\right]\left[S_{0}-x(\tau)-x(\tau-T)\right] \\
y_{u н}(\tau)=-\xi(\tau) \sin (\varphi)+\psi(\tau) \cos (\varphi) \\
x_{u H}(\tau)=-\xi(\tau) \cos (\varphi)-\psi(\tau) \sin (\varphi) \\
x(\tau)=x_{\text {mill }}(\tau)+x_{\text {tool }}(\tau) \\
y(\tau)=y_{\text {mill }}(\tau)+y_{\text {tool }}(\tau)
\end{array}\right.
$$

where $x_{\text {mill }}(\tau), y_{\text {mill }}(\tau)$ are respectively elastic movements of the elements of machine tool EES defined in $X-Y$ coordinate system;

$x_{\text {tool }}(\tau), y_{\text {tool }}(\tau)$ are respectively elastic movements occurring in modular tool subsystem defined in $X-Y$ coordinate system;

$\xi(\tau), \psi(\tau)$ are respectively elastic movements occurring in modular tool subsystem defined in the $\Xi-\Psi$ local coordinate system;

$x(\tau), y(\tau)$ are respectively the sum elastic movements of the elements defined in $X-Y$ coordinate system.

To solve the system of equations (10) and to fulfil the simulation it is convenient to use one of numerical methods for solving differential equation systems with software 
implementation on a computer [5].

To this end, a model of a heavy vertical lathe technological system is implemented by Simulink MatLab as a structural model of the process (Fig. 8).

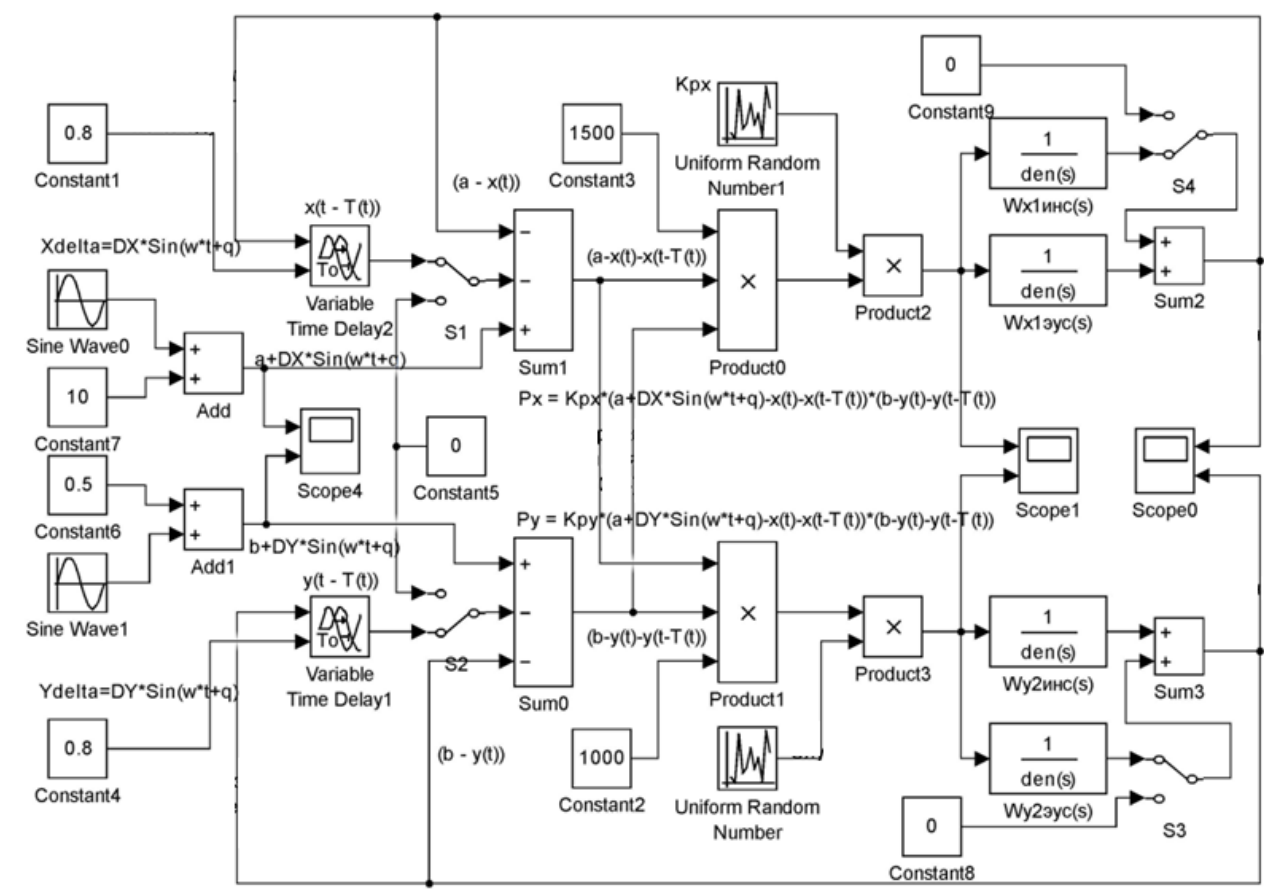

Figure 8. Structural model of turning process on a heavy vertical lathe in view of modular tool construction

The following notation is taken in the model shown in Fig. 8:

- Constant6, Constant7 are respectively tool feed $S_{0}, \mathrm{~mm} / \mathrm{rev}$, and target cut depth $t$,

$\mathrm{mm}$;

- Sine Wave0, Sine Wave1 are units of functions, simulating workpiece runout error owing to its inaccuracy of installation into the chuck, mm;

- Constant1, Constant4 are units designating the time of one revolution of workpiece to simulate tool movement to follow the "trace“, sec;

- Variable Time Delay1, Variable Time Delay2 are units of transfer functions $W_{x t}(s)$, $W_{y \tau}(s)$ determining the delay, arising from the cutting edge movement following the trace of the previous pass;

- Constant2, Constant 3 are respectively quantities of specific values of cutting force components $K_{p y}, K_{p x}, \mathrm{~N}$;

- Uniform Random NumberO, Uniform Random Numberl are units of functions, simulating appearance of random errors within the technological system during $\Delta K_{p}$ processing;

- Wxl(s)ees, Wyl(s)ees are units of transfer functions of the slider which define elastic movements $\Delta x$ and $\Delta y$ depending on the current value of cutting force components;

- Wxl(s)tool, Wyl(s)tool are units of modular tool transfer functions, determining elastic movements $\Delta x$ and $\Delta y$ depending on the current value of cutting force components.

Besides the described functional elements, the structure makes use of the units implementing mathematical operations of addition, subtraction and multiplication (Sum, Product), as well as controlled user keys for opening and interruption of the structure circuits, and also visualization units of output values: Scope 0 - of the tool movements $\Delta x(t)$ and $\Delta y(t)$; Scope 0 of the cutting force components $P_{x}(t)$ and $P_{y}(t)$.

The process of modeling and calculation of technological system dynamic 
characteristics is performed in the following order:

- timing is specified within which modeling of dynamic processes occurring in the technological system is done;

- original data are set: cutting depth $t_{0}, \mathrm{~mm}$ (Constant7); tool feed $S_{0}, \mathrm{~mm} / \mathrm{rev}$ (Constant6); inaccuracy of workpiece installation $D_{x}, D_{y}, \mathrm{~mm}$ (Sine Wave0, Sine Wave 1); time for workpiece one revolution, sec (Constant1, Constant4); specific values of cutting force components $P x, P y, \mathrm{~N} / \mathrm{mm}^{2}$ (Constant2, Constant3), coefficients of random errors (Uniform Random NumberO, Uniform Random Number1);

- current values of cutting force components $P x, P y$ are determined; besides, using switches $S 1$ and $S 2$, it is possible to enable/disable the signal, which determines phase response of the cutting process, and the numeric force values can be controlled by using the unit of signal visualization Scope 1;

- elastic displacement of technological system elements of a heavy vertical lathe is defined by numerical integration of transfer functions Wxl(s)ees, Wyl(s)ees of machine-tool and modular tool sub-system Wxl(s)tool, Wyl (s)tool; besides, modular tool subsystem can be excluded from the computing process by switches $S 3$ and $S 4$, and the computation results are visualized by unit $S$ cope 0 .

As an example, Fig. 9 shows tool displacement graphs $\Delta x(t)$ and $\Delta y(t)$ during processing as well as modification of the cutting force components $P_{x}(t)$ and $P_{y}(t)$.
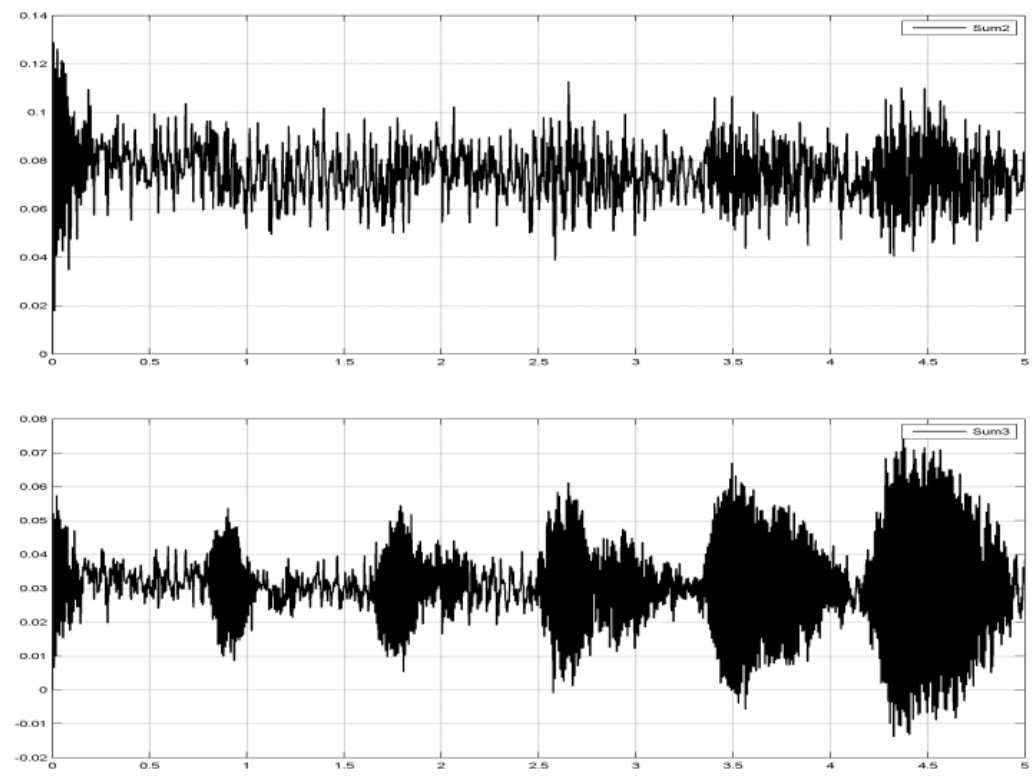

Figure 9. Design vibrogram of tool displacement $\Delta x(t)$ and $\Delta y(t): t=12 \mathrm{~mm} \mathrm{~s}=0.5 \mathrm{~mm} / \mathrm{rev} \mathrm{l}=9350 \mathrm{~mm}$

Conclusions. A design diagram of the ,slider-tool“ system is proposed. A technological system model of a heavy duty vertical turning and boring mill is obtained and implemented in Simulink MatLab package as a structural model of the process. Simulation of large nonrotational workpieces processing under various cutting conditions is carried out. The obtained results indicate occurrence of resonance phenomenon in the fastener assembly of a cutting tool when deployed by heavy vertical lathe under specified conditions.

\section{References}

1. Myronenko Ye.V. Obshchaya struktura matematycheskoy modely dlya opredelenyya enerhoeffektyvnykh tekhnolohycheskykh parametrov tokarnoy obrabotky detaley tyazheloho mashynostroenyya, Ye.V. Myronenko, H.P. Klymenko, V.V. Kalinichenko. Rezanye y ynstrument v tekhnolohycheskykh 
systemakh. Mezhdunarodnyy nauchno-tekhnycheskyy sbornyk. Khar'kov: NTU „KhPY“, 2015, no. 85, pp. $202-211$.

2. Levyn A.Y. Matematycheskoe modelyrovanye v yssledovanyyakh y proektyrovanyy stankov. M.: Mashynostroenye, 1978. 184 p.

3. Zharkov Y.H. Vybratsyy pry obrabotke lezvyynыm ynstrumentom. L., 1986. 184 p.

4. Strutyns'kyy V.B. Matematychne modelyuvannya metalorizal'nykh verstativ. Zhytomyr: ZhITI, 2002. $544 \mathrm{p}$.

5. Huzenko V.S. Dynamycheskyy raschet sbornoho ynstrumenta dlya tyazhelykh stankov v protsesse rezanyya, V.S. Huzenko, S.L. Myrantsov, L.M. Myrantsov. Naukovi pratsi Donets'koho natsional'noho tekhnichnoho universytetu. Seriya: Mashynobuduvannya i mashynoznavstvo. Donets'k: DonNTU, 2006. Vyp. no. 110, pp. $65-70$.

6. Effectiveness Rising of Wheel-Pairs Renewal by Cup-Tip Cassette Tool, Viktor Kovalov, Vitaliy Guzenko, Predrag Dašić, and Ivan Polupan. Applied Mechanics and Materials: Scientific Focus. Zurich, Switzerland: Trans Tech Publications, 2015. Vol. 806, pp. 94 - 98. ISSN: 1662-7482.

7. Myronenko E.V. Povyshenye enerhoeffektyvnosty protsessov obrabotky na tyazhelykh stankakh frezernorastochnoy hruppy, E.V. Myronenko, S.L. Myrantsov, V.L. Anosov. Visnyk NTU „KhPI“. Seriya: Tekhnolohiyi v mashynobuduvanni. Kharkiv: NTU „KhPI“, 2016, no. 5 (1177). pp. 104 - 109. ISSN 20790023.

\section{Список використаної літератури}

1. Мироненко, Е.В. Общая структура математической модели для определения энергоэффективных технологических параметров токарной обработки деталей тяжелого машиностроения [Текст] / Е.В. Мироненко, Г.П. Клименко, В.В. Калиниченко // Резание и инструмент в технологических системах. Международный научно-технический сборник. - Харьков: НТУ «ХПИ», 2015. - № 85. C. $202-211$.

2. Левин, А.И. Математическое моделирование в исследованиях и проектировании станков [Текст] / А.И. Левин. - М.: Машиностроение, 1978. - 184 с.

3. Жарков, И.Г. Вибрации при обработке лезвийным инструментом [Текст] / И.Г. Жарков. - Л., 1986. $-184 \mathrm{c}$.

4. Струтинський, В.Б. Математичне моделювання металорізальних верстатів [Текст] / В.Б. Струтинський. - Житомир: ЖІТІ, 2002. - 544c.

5. Гузенко, В.С. Динамический расчет сборного инструмента для тяжелых станков в процессе резания [Текст] / В.С. Гузенко, С.Л. Миранцов, Л.М. Миранцов // Наукові праці Донецького національного технічного університету. Серія: Машинобудування і машинознавство. Донецьк: - ДонНТУ, 2006. Вип. № 110. - С. $65-70$.

6. Effectiveness Rising of Wheel-Pairs Renewal by Cup-Tip Cassette Tool, Viktor Kovalov, Vitaliy Guzenko, Predrag Dašić, and Ivan Polupan. Applied Mechanics and Materials: Scientific Focus. Zurich, Switzerland: Trans Tech Publications, 2015. Vol. 806, pp. 94 - 98. ISSN: 1662-7482.

7. Мироненко, Е.В. Повышение энергоэффективности процессов обработки на тяжелых станках фрезерно-расточной группы [Текст] / Е.В. Мироненко, С.Л. Миранцов, В.Л. Аносов // Вісник НТУ «ХПІ». Серія: Технології в машинобудуванні. - Харків : НТУ «ХПІ», 2016. - № 5 (1177). - С. 104 109. - ISSN 2079-0023.

\section{УДК 621.9.15}

\section{МОДЕЛЬ ТЕХНОЛОГІЧНОЇ СИСТЕМИ ВАЖКИХ КАРУСЕЛЬНИХ ВЕРСТАТІВ}

\section{Свгеній Мироненко; Сергій Міранцов; Денис Гузенко}

\section{Донбаська державна машинобудівна академія, Краматорськ, Украӥна}

Резюме. Запропоновано модель технологічної системи важкого карусельного верстата. Розглянтоо структурну модель технологічної системи зі збірним інструментом для важких верстатів та ї̈ складові. Запропоновано розрахункову схему системи «повзун - інструмент». Представлено імітаційну модель поведінки технологічної системи, яка реалізована у програмному середовищі Simulink MatLab.

Ключові слова: важкий карусельний верстат, технологічна система, прочес різання, збірний інструмент, імітаційна модель.

Отримано 02.06.2016 